\title{
Identification of Gastrointestinal Endoparasite in Bawean Deer (Axis kuhlii) and Spotted Deer (Axis axis) at Bratang Flora Park - Surabaya
}

\author{
Identifikasi Jenis-Jenis Endoparasit yang Terdapat pada Saluran Pencernaan Rusa \\ Bawean (Axis kuhlii) dan Rusa Tutul (Axis axis) di Taman Flora Bratang - Surabaya \\ ${ }^{1)}$ Hartono, ${ }^{2)}$ Endang Suprihati, ${ }^{3)}$ Erma Safitri, ${ }^{2)}$ Nunuk Dyah Retno L, ${ }^{2)}$ Mufasirin, ${ }^{2)}$ Kusnoto \\ ${ }^{1)}$ Student, Faculty of Veterinary Medicine, Universitas Airlangga \\ ${ }^{2)}$ Department of Veterinary Parasitology, Faculty of Veterinary Medicine, Universitas Airlangga \\ 3) Department of Veterinary Reproduction, Faculty of Veterinary Medicine, Universitas Airlangga \\ Received: 03-08-2019, Accepted: 10-08-2019, Published Online: 16-o8-2019
}

\begin{abstract}
The purpose of this study is to identify the endoparasites of Spotted Bawean Deer (Axis kuhlii) and Deer (Axis axis ) at Surabaya Flora Park. The research was conducted in December 2018 - January 2019 used total 6o specimen of sample faeces, consist of 30 sample of bawean deers faeces and 30 sample of spoted deers faeces, the samples analyzed at the Department of Parasitology Veterinary, Faculty of Veterinary Medicine, Universitas Airlangga. The results of the study found positive endoparasites on examination, samples of Bawean deer faeces (Axis kuhlii) and Spotted deer faeces(Axis axis) in Baratang Flora Park Surabaya found that 26 positive samples from 6o samples were obtained. Positive endoparasitic samples are protozoa at the stage of oocyst, namely Eimeria sp. 6 (10\%) samples, worm eggs from the Nematoda class, Haemonchus sp. 20 (33.33\%) and whereas endoparasites from other stages and classes were not found. The results of the analysis used Chi-Square test and showed no significantly differences degree of gastrointestinal endoparasite infection of Bawean deer (Axis kuhlii) and Spotted deer (Axis axis) ( $\mathrm{p}>0.05)$.
\end{abstract}

Keywords: identification, gastrointestinal, endoparasites, Axis kuhlii, Axis axis

\section{Pendahuluan}

Rusa adalah satwa liar yang memiliki nilai estetika dan dapat dijadikan sebagai satwa pajangan dalam taman terutama rusa Bawean (Axis kuhlii) dan rusa Tutul (Axis axis). Rusa sekaligus memiliki potensi ekonomi karena dapat menghasilkan kulit, velvet (tanduk muda) dan daging (Garsetiasih dan Takandjanji, 2006). Potensi yang dimiliki rusa mengakibatkan perburuan tidak terkendali, sehingga populasi rusa mengalami penurunan. Salah satu upaya dalam mengatasi penurunan populasi rusa adalah dengan membangun penangkaran.

Penangkran adalah upaya yang dilakukan pemerintah dalam menanggulangi berkurangnya populasi fauna terutama pada rusa, di habitat yang menyerupai keadaan aslinya (exsitu) salah satunya Taman Flora. Satwa yang berada di Taman Flora mempunyai dampak negatif, antara lain terjangkitnya satwa dengan penyakit karena Indonesia beriklim tropis dan memiliki kelembaban yang cukup tinggi, sehingga dapat menunjang perkembangbiakan parasit. Infeksi oleh parasit dapat mempengaruhi keadaan fisiologis satwa, misalnya penurunan bobot tubuh, penurunan tingkat reproduksi, berkurangnya aktivitas, stress, luka dan menjadi lebih agresif (Widodo, 2013).

Banyak faktor yang dapat memicu penyakit hinggap pada hewan, bahkan satwa liar yang bebas dialam sekalipun, apalagi dalam kondisi terkurung. Penyakit dapat menyerang terutama pada kondisi satwa yang lemah, stres, lingkungan yang kotor, serta perawatan satwa yang kurang baik. Pada beberapa kasus, penyakit endoparasit ditularkan melalui kontak langsung dengan hewan yang terinfeksi dan pada kasus lain dapat dijumpai penularan melalui air minum yang mengandung endoparasit (Achmadi, 2005).

Penyakit endoparasit adalah yang hidup didalam tubuh hewan yang merupakan salah satu faktor penting yang perlu diperhatikan dalam pengelolaan penangkaran seperti kebun binatang atau taman satwa (Rahmah dkk., 2013). Berbagai faktor yang mendukung terjadinya infeksi parasit tidak hanya berasal dari kondisi manajemen biosekuriti kandang, akan tetapi dapat juga berasal dari faktor di dalam kandang antara lain kekurangan nutrisi, perkelahian dan 
cekaman stres. Faktor pemacu stres antara lain perubahan habitat dan iklim serta tingginya kontak dengan manusia (Geraghty dkk., 1982 ; Morgan dan Nath dkk., 2012). Faktor lain antaranya rusa merupakan hewan ruminansia yang biasanya memakan dedaunan dari tumbuhan semak, alang - alang (imperata cylindrica). Kelompok hijauan yang menjadi pilihan rusa adalah terdiri dari rerumputan, tumbuhan semak, tumbuhan menjalar. Pakan yang dipilih hanya pada bagian tumbuhan yang berumur muda (Semiadi, 2004), jika terdapat infestasi endoparasit pada pakan dan minum rusa ini maka kemungkunan infeksi dapat terjadi.

Informasi mengenai parasit pada satwa penangkaran dapat menjadi dasar yang mendukung kesuksesan usaha penangkaran satwa liar terutama pada penangkaran rusa. Data ini selain dapat digunakan sebagai bahan untuk menentukan pengambilan kebijakan perlakuan medik terhadap satwa yang ditangkarkan, juga dapat sebagai bahan acuan untuk mengetahui potensi patogenitas parasit pada hewan mengingat banyak jenis endoparasit yang bersifat zoonosis (Nugroho dan Purwaningsih, 2015).

\section{Materi dan Metode Penelitian Tempat dan Waktu Penelitian}

Pengambilan sampel dilakukan di Taman Flora Surabaya, sedangkan pemeriksaan sampel feses dilakukan di Laboratorium Departemen Parasitologi Fakultas Kedokteran Hewan Universitas Airlangga. Penelitian ini dilaksanakan pada Bulan Desember 2018 sampai Januari 2019.

\section{Alat dan Bahan Penelitian}

Alat yang digunakan dalam penelitian ini adalah sendok plastik, kantung plastik, mikroskop, gelas, pipet, gelas pengaduk, saringan, mortir, tabung centrifuge, centrifuge, objek glass, cover glass, kertas label dan opti lab.

Penelitian ini menggunakan total 60 sampel feses yang terdiri dari 30 sampel feses rusa Bawean dan feses rusa Tutul 30 sampel yang diambil dari Taman Flora Bratang Surabaya. Bahan lain yang digunakan untuk pemeriksaan yaitu larutan gula jenuh, aquades, air PDAM, formalin $10 \%$ dan kalium dikromat.

\section{Metode Pemeriksaan}

Sampel feses diambil sebanyak 5 gram kemudian dimasukkan ke dalam gelas plastik kemudian ditambahkan aquadest dengan perbandingan 1:10. Campuran feses dan aquadest diaduk hingga homogen kemudian disaring dan dimasukkan ke dalam tabung sentrifus, selanjutnya sentrifus selama 5 menit dengan kecepatan 1500 rpm. Setelah selesai disentrifus, supernatan dibuang sedangkan endapam ditambah aquadest lagi seperti tahap sebelumnya kemudian di sentrifus kembali dengan waktu dan kecepatan yang sama, proses diulang 3 kali atau sampai supernatan terlihat jernih. Supernatan dibuang hingga tidak tersisa kemudian tambahkan larutan gula sukrosa jenuh pada tabung sentrifus menggunakan pipet pasteur sampai $1 \mathrm{~cm}$ dari mulut tabung dan disentrifugasi dengan kecepatan $1500 \mathrm{rpm}$ selama 5 menit. Letakkan tabung sentrifus pada rak tabung kemudian secara perlahan ditetesi larutan gula sukrosa jenuh lagi hingga cairan terlihat cembung pada mulut tabung sentrifus, setelah itu tabung ditutup dengan coverglass, biarkan 5 menit. Coverglass diangkat dan letakkan pada objekglass dan diamati di bawah mikroskop dengan perbesaran 100x-400x (Suwanti dkk., 2010).

\section{Analisis Data}

Sampel feses dinyatakan positif apabila ditemukan endoparasit. Sampel feses yang didapat dari Taman Flora Bratang-Surabaya diperiksa secara berurutan dengan metode natif, sedimentasi dan apung. Bila sampel mengandung telur endoparasit maka sampel tersebut dinyatakan sebagai sampel positif.

Analisis statistik dengan rumus Chi-Square dengan menggunakan progarm IBM SPSS Statistics versi 23 untuk mengetahui tingkat perbedaan (protozoa dan helminth yang terdapat pada feses rusa Bawaean dan rusa Tutul di tamana flora Bratang Surabaya) terhadap infeksi endoprasit saluran pencernaan. Prevalensi dihitung berdasarkan sampel $+/$ total sampel dinyatakan dalam \%.

\section{Hasil dan Pembahasan}

Sampel feses rusa diambil di Taman Flora Bratang Surabaya Timur, jumlah total feses yang diambil yaitu 6o sampel yang di dapat dari rusa Bawean 30 sampel dan rusa Tutul 30 sampel dengan pengambilan sampel secara acak. Pemeriksaan feses dilakukan dengan metode natif, sedimen, dan apung.

Berdasarkan hasil pemeriksaan, sampel feses rusa Bawean (Axis kuhlii) dan rusa Tutul (Axis axis) di Taman Flora baratang Surabaya 
ditemukan hasil positif mengandung endoparasit sebanyak 26 (43,33\%) dari total sampel, dapat diketahui pada Tabel 1. Pada pemeriksaan morfologi endoparasit dari semua sampel yang positif hanya ditemukan protozoa dari stadium ookista yaitu Emeria sp. (Gambar 2.). Pada telur cacing dari kelas Nematoda yaitu haemonchus sp. (Gambar 3.) dan sedangkan endoparasit dari stadium dan kelas yang lain tidak ditemukan.

Tabel 1. Persentase endoparasit saluran pencernaan pada rusa Bawean dan rusa Tutul di Taman Flora Bratang Surabaya

\begin{tabular}{cccc}
\hline \multirow{2}{*}{$\begin{array}{c}\text { Sampel } \\
\text { feses }\end{array}$} & \multicolumn{2}{c}{ Endoparasit } & \multirow{2}{*}{ Jumlah } \\
\cline { 2 - 3 } & Negatif & Postif & \\
\hline Rusa & 15 & $15(50 \%)$ & 30 \\
Bawean & $(50 \%)$ & $100 \%)$ \\
Rusa & 19 & 11 & 30 \\
Tutul & $(63,33 \%)$ & $(36,66 \%)$ & $(100 \%)$ \\
\hline \multirow{2}{*}{ Total } & 34 & 26 & 60 \\
& $(56,66 \%)$ & $(43,33 \%)$ & $(100 \%)$
\end{tabular}

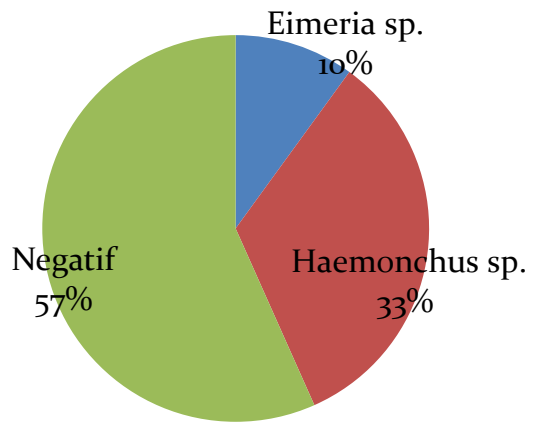

Gambar 1. Diagram jumlah endoparasit yang ditemukan pada rusa Bawean dan rusa rusa Tutul di Taman Flora Bratang Surabaya.

Protozoa yang di temukan adalah Eimeria sp. berdasarkan buku panduan Levin (1995), dapat diidentifikasi berdasarkan bentuk ookista. Umumnya ookista berbentuk bulat, bulat telur (ovoid) dan silinder yang memiliki ukuran 12-45 $\mu \mathrm{m}$. Stadium Ookista pada Eimeria sp., ookista yang sudah bersporulasi memiliki 4 sporokista, masing-masing berisi 2 sporozoit dari hasil pemeriksaan feses pada rusa Bawean (Axis kuhlii) dan rusa Tutul (Axis - axis) pada Gambar 2.

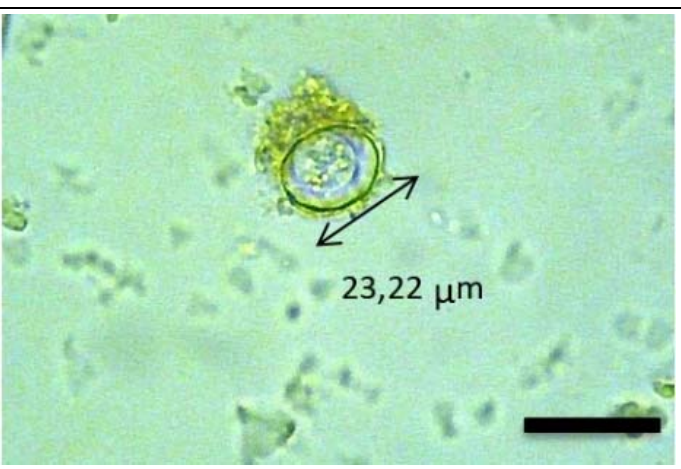

Gambar 2. Eimeria sp. pembesaran $400 x$ (panjang skala :50 $\mu \mathrm{m}$ ).

Hasil penelitian menemukan protozoa pada saluran pencernaan rusa Bawean dan rusa Tutu pada stadium ookista yaitu Eimeria sp. 6 (10\%) dari 6o sampel positif. Prevalensi pada penelitian ini cukup tinggi dibandingkan dengan beberapa penelitian lainnya yakni pada penelitian Zulfilkar (2015) di Taman Pintu Satu Universitas Hasanuddin Makasar dari 33 sampel terdapat 1 (3,03\%) sampel positif Eimeria sp. stadium ookista.

Gambaran mikroskopis yang ditemukan yaitu stadium kista Eimeria sp. termasuk dalam kelas conoidasida yang tersebar secara luas diseluruh dunia. Spesies ini menyerang saluran pencernaan dari ruminansia dan berukuran 12$45 \mu \mathrm{m}$ tergantung dari spesiesnya. Pada hasil penelitian ini cukup besar yang berukuran 30,1 $\mu \mathrm{m}$. Ookista ini dapat ditemukan dengan metode apung. Spesies dari genus Eimeria yaitu Eimeria sp. dapat menyebabkan infeksi akut pada usus halus rusa sehingga menyebabkan coccodiosis (Georgis, 2014).

Eimeria sp. dapat menyebabkan Coccidial bersifat universal pada domba dan kambing, dan coccidiosis dapat menjadi masalah yang signifikan pada hewan muda dari kedua spesies tersebut. Coccidian adalah anggota dari Apicomplexa protistan filum, subkelas Coccidiasina, parasit intraseluler, ditandai pada beberapa tahap siklus hidup oleh suatu kompleks organel khas apikal pada satu ujung organisme. Anggota genus Eimeria dan Isospora homoxenous dengan perkembangan seksual dan aseksual yang terjadi dalam satu host. Etiologi coccidiosis pada domba dan kambing dipersulit oleh kesamaan morfologis dari coccidia yang menginfeksi spesies ini (Gelberg, 2012). bagian dari spesies coccidian dan didistribusikan ke seluruh dunia (Zucca, 200o). Pematangan Coccidia sp. melewati tiga fase. Fase pertama adalah schizogony diikuti oleh fase kedua gamogony. 
Kedua fase berkembang di sel tuan rumah. Tahap ketiga berkembang di lingkungan dan disebut sporogony (Gylstorff dan Grimm., 1998). Tahap infeksi dari coccida adalah selama proses pematangan ketika oocyst sporulated dibagi menjadi sporocysts dengan sporozoites (Greiner dan Ritchie., 1994).

Telur cacing yang ditemukan kemudian diidentifikasi berdasarkan buku panduan Ballweber (2001), Telur cacing yang ditemukan berbentuk oval, berwarna abu-abu dengan selubung tipis berukuran 70-110 x 30-50 $\mu \mathrm{m}$, dengan mengandung morula dengan banyak sel. Gambar telur cacing dari hasil pemeriksaan feses pada rusa Bawean (Axis kuhlii) dan rusa Tutul (Axis - axis) dapat dilihat pada Gambar 3.

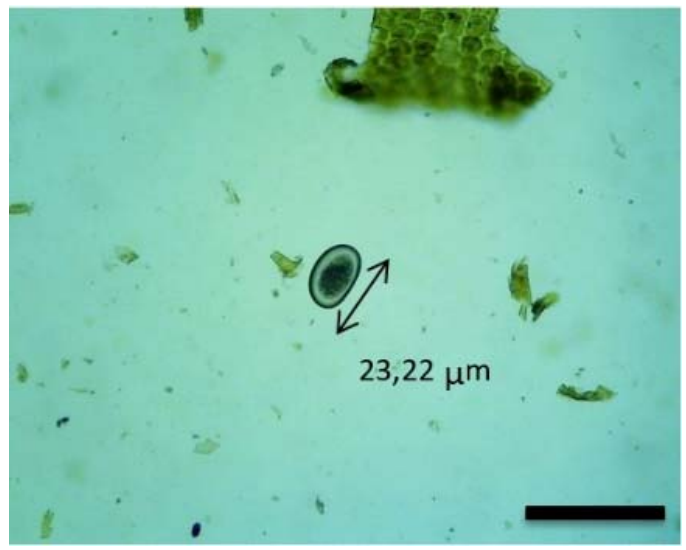

Gambar 3. Telur dari cacing haemonchus sp., dengan pembesaran 100x (panjang skala :200 $\mu \mathrm{m})$.

Hasil penelitian ini di temukan helminth pada kelas nematoda yaitu haemoncus sp. 20 (33,33\%) dari 6o sampel positif haemoncus sp. Prevalensi pada penelitian ini cukup tinggi dibandingkan dengan beberapa penelitian lainnya yakni pada penelitian Zulfilkar Barsul (2015) di Taman Pintu Satu Universitas Hasanuddin Makasar dari 33 sampel terdapat 1 (3.03\%) sampel positif helmint pada kelas nematoda yaitu haemoncus sp. saluran pencernaan rusa. Gambaran mikroskopis yang ditemukan yaitu haemoncus sp.. Telur cacing ini berbentuk oval, berwarna abu-abu dengan selubung tipis berukuran 70-110 x 30-50 $\mu \mathrm{m}$, dengan mengandung morula dengan banyak sel 16-32 Ballweber (2001). Haemonus dapat menyebabkan penyakit haemonchosis dengan jumlah 10.000 telur per gram ditandai dengan adanya gejala anemia (Bowman, 2009).

Hemonchus sp. termasuk parasit monoksenosa, karena hanya membutuhkan satu individu inang atau hospes dalam menyelesaikan seluruh siklus hidupnya. Siklus hidupnya termasuk bertipe langsung, dimana parasit hanya membutuhkan satu hospes, yaitu hospes definitif sebagai hospes akhir, dengan kata lain disini tidak diperlukan hospes perantara (Anderson, 2000).

Selama di dalam tubuh hospesnya, parasit menghasilkan pengaruh buruk dengan cara bermacam-macam. haemoncus sp. menyebabkan anemia normositik, anemia hipokromik. Hipoalbuminemia terjadi sebagai akibat kehilangan darah pada ternak, menyebabkan akumulasi cairan pada rongga perut dan edema perifer pada rahang (sering disebut sebagai bottle jaw atau rahang botol). Abomasitis sebagai akibat infeksi cacing, dapat mengganggu daya cerna dan penyerapan protein, kalsium, dan fosfor. Pendarahan petechial sampai ecchymotic mungkin terlihat pada mukosa abomasum (Ballweber, 2001). Haemonchus sp. adalah penghisap darah yang rakus, pada infeksi yang akut, setiap cacing dapat menghisap darah o,049 ml/hari (Partodiharjo dan Suryadi, 1998).

Sesuai dengan data dari hasil pemeriksaan sampel feses pada rusa Bawean dan rusa Tutul di Taman Flora Bratan Surabaya, analisis data juga dilakukan dengan menggunakan chi-square test untuk mengetahui ada atau tidaknya perbedaan yang nyata antara kejadian infeksi endoparasir pada rusa Bawean dan rusa Tutul, sehingga didapatkan hasil yaitu p>0.05 yang berarti tidak ada perbedaan yang nyata antara infeksi endoparasit saluran pencernaan rusa Bawean dan rusa Tutul.

\section{Kesimpulan}

Identifikasi jenis endoparasit pada saluran pencernaan rusa Tutul dan rusa Bawean di Taman Flora Bratang di Surabaya ditemukan Eimeria sp. dan Haemonchus sp. Perbedaan Endoparasit pada saluran pencernaan rusa Bawean ditemukan protozoa pada stadium ookista yaitu Eimeria sp. sebanyak 4 (13,33\%) pada telur cacing dari kelas Nematoda yaitu Haemonchus sp. $11(36,66 \%)$ dan rusa Tutul protozoa pada stadium ookista yaitu Eimeria sp. sebanyak 2 (6,66\%) pada telur cacing dari kelas Nematoda yaitu Haemonchus sp. 9 (30\%) di Taman Flora Bratang di Surabaya.

\section{Daftar Pustaka}

Achmadi, A. 2005. Satwa yang Menularkan Penyakit: Satwa Seperti Halnya Manusia, Tidak Terbebas dari Penyakit. LIPI. Bogor. 
Anderson, R.A. (2000) Nematode parasites of vertebrates: Teir developmen and transmisson 2 ed. CABI Publising. UK.

Bowman, D.D. 2009. Georgis' Parasitology for veterinarians $9^{\text {th }} \mathrm{Ed}$. Saunders Elsevier. Missouri. 99.

Garsetiasih, R., dan M. Takandjandji. 2006. Model penangkaran rusa. Dalam: Konservasi dan Rehabilitasi Sumberdaya Hutan. Prosiding Ekspose Hasil-Hasil Peneltian; Padang 20 September 2006. Bogor: Pusat Penelitian dan Pengembangan Hutan dan Konservasi Alam, Departemen Kehutanan.

Georgis. 2014. Parasitology for Veterinarians 1oth Edition. Eslevier. St. Louis. Missouri US.

Geraghty V., J Mooney., and K Pike. 1982. A Study of parasitic Infections in Mammals and Birds at The Dublin Zoological Garden. VetResCommun5: 343-348.

Greiner, E and B. Ritchie (1994). Parasites. In Avian Medicine, Principles and Application. Wingers Publishing. Pp 1006-1029.

Gylstorff I., and F Grimm. (1998). Vogelkrankheiten. 2nd ed. Verlag Eugen Ulmer.

Levine, N.D. 1995. Buku Pelajaran Parasitologi Veteriner penerjemah: Gatut Ashadi, Wardiarto, editor. Gadjah Mada University Press. Yogyakarta

Morgan K.N., and C.T. Tromborg. 2007. Sources of stress in captivity. App Anim Behav Sci 102: $262-302$

Murtidjo, B.A. 1994. Metode Riset Epidemiologi. Gadjah Mada University Press.Yogyakarta.

Nath, B.G, S. Islam., A. Chakraborty. 2012. Prevalence of parasitic infection in captive non human primate of Assam States Zoo, India. VetWorld 5 (10): 614-616.

Nugroho H.A., dan E. Purwaningsih. 2015. Nematoda parasit gastrointestinal pada satwa mamalia di penangkaran Pusat Penelitian Biologi LIPI Cibinong, Jawa Barat. Pros Sem Nas Masy Biodiv Indon 1: 1785-1789.

Partodiharjo, S dan Suryadi, H. (1998) Studi tentang penggunaan serum domba pascavaksinasi larva tiga (L3) cacing Haemonchus contortus iradiasi pada kelinci. Diakses pada tanggal 11 Desember 2013.

Prianto, L.A., P.U. Juni., Tjahaya dan Darwanto. 2006. Atlas Parasitologi Kedokteran. Gramedia Pustaka Utama. Jakarta

Rahmah, F., Dahelmi dan S. Salmah. 2013 Cacing Parasit Saluran Pada Hewan Primata di Taman Satwa Kandi Kota Sawahlunto Provinsi Sumatra Barat. Jurnal Biologi Universitars Andalas 2: 14-19

Semiadi, G. 2004. Sifat Biologi Rusa Bawean(Axis kuhlii). Puslit Biologi LIPI Press, Bogor.

Semiadi, G. Dan R. Taufiq. 2004. Panduan Pemeliharaan Rusa Tropis. Puslit Biologi LIPI Press, Bogor.

Suwanti, L.T., N.D.R. Lastuti. dan E. Suprihati. 2010. Petunjuk Praktikum Ilmu Penyakit Protozoa. Fakultas kedoteran Hewan, Universitas Airlangga. Surabaya

Syah, S.P., E. Saswiyanti. dan I.S. Nurhayati, 2011. Cryptosporidiosis pada Manusia dan Hewan. PS Kesehatan Masyarakat Veteriner. Institut Pertanian Bogor.

Takandjandji, M. 20o8. Teknik Penangkaran Rusa Timor (Rusa Timorensis Blainville, 1822)

Timreck, T.C. 2004. Epidemiologi Suatu Pengantar, penerjemah : Munaya Fauziyah,Apriningsih, Palupi Widyastuti, Mulia Sugiarti, Ratnawati, editor EGC. Jakarta. 2

Tjahjati dan Subroto. 2011:13. Pedoman Pengobatan Pada Hewan. Bentang Pustaka.

Widodo, H. 2013. Parasitologi Kedokteran. Medika: Yogyakarta. Winaya, I.B.O., I.K. Berata., dan I.A.P. Apsari., 2011. Kejadian Balantidiosis pada Babi Landrace. Jurnal Veteriner. $12: 65-68$.

Wulida, A. 2013. Identifikasi Helmintiasis Gastrointestinal Pada Rusa Bawean (Axis kuhlii) di Kebun Bibit Surabaya dan Taman Safari Indonesia II [Skripsi]. Fakultas Kedokteran Hewan. Universitas Airlangga.

Yulfi, H. 2006. Protozoa Intestinalis. Universitas Sumatera Utara Repository. Medan.

Zucca, P (2000). Infectious diseases. Avian medicine. Samour, J.(ed)(London, Tokyo. Mosby). Pp219- 244. 
Zulfikar B. 2015. Identifikasi Endoparasit Pada Saluran Pencernaan Rusa Tutul (Axis axis) Di Taman Pintu Satu Universitas Hasanuddin Makasar, fakultas kedokteran hewan, Universitas Hasanudin. 